\title{
A COOPERATION PROJECT BETWEEN THE STATE UNIVERSITY OF GHENT AND THE UNIVERSITY OF NAIROBI ON THE LAW OF THE SEA, OCEAN MANAGEMENT AND MARINE POLICY
}

\author{
Eddy SOMERS \\ Faculty of Law, RUG \\ Universiteitstraat 4 \\ B-9000 Gent
}

CURRENT RESEARCH INTEREST: law of the sea; international public law; international environmental law with regard to the marine environment

\section{SUMMARY}

This contribution gives an idea of the necessity of cooperation in the field of the law of the sea, ocean management and marine policy towards East Africa. It is demonstrated through a substantial analysis of the development of the law of the sea that such a cooperation on an academic level can be a valuable means for further development in these fields for Third World States. A general description of a present cooperation project with Kenya is given as an example of this kind of approach.

KEY WORDS: development cooperation, international law, Kenya, law of the sea 


\section{INTRODUCTION}

1. Development cooperation projects concerning marine sciences have been going on between Belgian universities and research institutions and universities in Kenya since 1985. Especially the Free University of Brussels and the State University of Ghent took a particular interest in the development of projects on oceanography and marine biology. Within the field of international law however the necessity for expanded academic activity in the domains of the law of the sea, ocean management and marine policy has been rendered particularly important by the adoption of the United Nations Convention on the law of the sea in December 1982.

\section{THE DEVELOPMENT OF THE LAW OF THE SEA AND THE THIRD WORLD STATES}

2. The stability attained in the law of the sea in the second half of the 19th century warranted the codification of its rules. To this task many an Institution and Organisation was called upon. Various bodies essayed their own codes in which a surprising degree of unanimity was reached (Institut de droit international; International Law Association; several national societies of international law). The first important official codification attempt was made by the Hague Codification Conference of 1930, which was called by the League of Nations to codify among other things the law relating to territorial waters. The Codification Conference was thoroughly prepared and was directed at establishing what the rules of international law then were. Consequently the emphasis at the conference was rather legal than political. However the Hague Conference failed for a political reason, namely the fact that no general agreement could be reached for a 3 mile limit for fisheries. The crisis of the 1930s and World War II prevented to reconvene the Conference.It was not until the United Nations was set up that it proved possible to return to the codification of the law of the sea.

3. From its early existence on the International Law Commission (ILC) recognised that the law of the sea was one of the subjects for codification. So the ILC started its work in 1950 with the understanding that not only the codification of the law of the sea was its mandate, but also the progressive development of these legal rules. This implies that the ILC not only described what the law of the sea was at that moment, but it also gave the direction alongside which it should develop. After years of intensive work the ILC submitted in 1956 Draft Articles to the General Assembly of the United Nations. The Draft Articles were intended to form a comprehensive text and were placed before the specially convened First Geneva Conference of the Law of the Sea in 1958. Owing to the fact that the Draft Articles were submitted by subject-matter to different Committees at the Conference four separate Conventions 
instead of one emerged: the Convention on the territorial sea and the contiguous zone; the Convention on the high seas; the Convention on the continental shelf and the Convention on the Conservation of fisheries. The emergence of four separate conventions opened up the possibility for states to adhere to parts only of what was meant to be an over-all scheme. By not respecting the comprehensive character of the law of the sea rules, inevitably distortions occurred, since the balance between the different parts was not always respected.

The Geneva Conventions of 1958 are a mixture between codification and progressive development of international law. The difference between the two is however not always easy to grasp. All four Conventions have come into force and have been ratified by several States. Nevertheless only a minority of the States is bound by the package. For those States that did not become a party to (some of) the Conventions, they are bound by the Geneva rules only to the extent that these are customary law. It is unfortunately not always very simple to find out whether or not a conventional rule also forms part of customary law.

4. The 1958 Geneva Conference did not succeed in agreeing on the issues of the breadth of the territorial sea and the limits of fishery zones. For this reason the General Assembly convened a Second Law of the Sea Conference in Geneva in 1960. The fundamental problem of jurisdictional delimitation ratione loci concerning the territorial sea and fisheries could also not be solved at this Conference. Consequently the issue could not be regulated by convention and remained subject to the unilateral action of coastal States.

5. The Geneva Conventions contended several lacunae concerning the rights and competences of the coastal States, a situation that repeatedly initiated conflicts. This mainly traditional body of rules, besides, seemed to be very rapidly no longer suitable to cope with the changing uses of the sea and its natural resources. Due to a genuine technological revolution, international navigation alienated remarkably fast from the existing Geneva rules (increase of tonnage; new types of ships...). The enormous increase in fish catch between 1950 and 1970 (20 million tons - 70 million tons/annum) and the emergence of new techniques and possibilities for off shore exploitation were all factors indicating that the basic principles of the traditional Geneva law of the sea were no longer valid.

6. Apart from these predominantly technological reasons for the need of a new law of the sea, important political developments cannot be overlooked. While in 1958 exactly 86 states were represented at the First Law of the Sea Conference, 137 States were present at the opening of UNCLOS III in 1973. Most of the new States that came into being after the colonial era had definitely come to an end, experience very little affinity with the traditional law of the sea. The bulk of these States wishes to 
advance their own views on the development of the law of the sea and want the traditional eurocentric view to be substituted by them. They want to stand up for the defence of their own national interests and to work out the legal development of the sea consequently.

7. Another factor that has influenced the development of the law of the sea is the outspoken presence of international organisations. We have now reached an era in which international relations are more and more influenced and even dominated by the work of international organisations. Within the field of the law of the sea also, institutionalised forms of international cooperation are turned to in order to cope with the emerging problems. The regional and subregional levels seem to be most appropriate for decision making in the law of the sea as in the other branches of international law.

Finally our modern society is unmistakably confronted with the new problem of distribution of scarcity. The idea of the inexhaustible character of the resources of the sea is definitely left behind. The sea and its resources seem no longer capable to live up to the extreme demands of our highly industrialised society. The increased intensive uses of the sea necessarily implies a more rational distribution of its resources. The traditional law of the sea is not at all the most suitable instrument to cope with this evolution. Freedom of the seas, the corner stone of the traditional law of the sea, can only serve well those States that possess the skills for making use of it. These States are and remain the countries of the industrialised world. Therefore, this traditional concept of freedom of the seas was no longer regarded as a valid instrument to further the interests of the developing world. Besides, we may not forget that for many of the States in development, the oceans are the only source they can freely turn to for living and non-living natural resources. Consequently the extension of national jurisdiction over large areas of the sea has practically been inevitable. Moreover, this evolution tends to substitute the more primitive exploitation system by a system of rational policy of development. With this system fully working, problems like overfishing and marine pollution can be avoided and the oceans can keep their function as a world source of food. As a matter of fact the Geneva Conventions had barely come into force when the basis for this traditional approach of the law of the sea became obsolete.

8. It was the question of access to the mineral resources of the deep sea that initiated the Third Law of the Sea Conference (UNCLOS III). The problem was raised by Malta in 1967, when the Maltese ambassador to the United Nations, A. Pardo, drew the attention of the General Assembly to the discoveries of manganese nodules on the deep seabed. One thought at the time - due to exaggerated expectations - that the problems of the developing countries could be relieved if the benefit of exploiting these resources was diverted from the industrial countries. It was proposed to put the 
exploitation of these resources in the hands of an international authority and to declare the deep seabed and its natural resources beyond national jurisdiction "common heritage of mankind".

9. UNCLOS III which held its first substantial meeting in Caracas in 1974, received a mandate over the full range of comtemporary questions of the law of the sea. Unlike the Geneva Conferences the International Law Commission was not involved in the preparation of the Conference. The difficult task of preparing the Conference was entrusted with the Sea Bed Committee. So the Conference started in an unstructured fashion. The Sea Bed Committee acted as a sounding box, not as a genuine preparatory committee. There was no text to be put to debate and to be voted upon. Instead, the Conference was faced with a variety of proposals, some coincidental more or less, some antithetical more or less. If these had been subjected to the procedures of the Geneva Conference, requiring motion and vote before a text was available for a plenary vote, the Conference would never end. Accordingly the Sea Bed Committee was divided into three committees. The first was concerned with deep sea mining, the second with the standard subjects of jurisdiction, and the third with a miscellany, including pollution and scientific research.

The Third United Nations Conference on the Law of the Sea convened on December 3rd 1973. Nine years and eleven sessions later, the Law of the Sea Convention finally came into being. Due to the majority position of the developing countries at the Conference, the industrialised States could not accept that decisions were made with a two third majority. So after complicated negotiations, the Rules of Procedure contended a new way of decision making. The procedure was that finality was tried to be reached by consensus rather than by voting. The supposition was that, if the Chairman of each Committee could define a consensus on a particular point that would constitute the text. So it can hardly be a surprise that decision making at the Conference was a slow and difficult negotiating process. In this negotiating process an important stand was taken by the President of the Conference, H.S. Amerasinghe (was succeeded by T. Koh in 1980). Substantial influence was also lain with the Presidents of the three main Committees of the Conference. It were the three Presidents that, in 1975, produced a basic text which resulted in the Informal Single Negotiating Text (ISNT). This ISNT was replaced in 1976 by a revised version, the Revised Single Negotiating Text (RSNT) that was substituted in 1977 by the Informal Composite Negotiating Text (ICNT). This text was the first comprehensive document with a preamble and final clauses, but had no greater status than its predecessors. Finally in 1980 a Draft Convention on the Law of the Sea was published with the intention that it should go forward for final negotiation and adoption. However due to substantial objections from the United States, a vote was necessarry to adopt the Draft Convention. The vote took place on April 30th, 1982. Voted against: Israel, Turkey, the United States and Venezuela, whilst 17 States 
abstained.. 130 States finally adopted the Draft, which was opened for signature in Montego Bay at December 10, 1982.

10. For the moment the Convention is already signed by 159 States, whilst 43 States have ratified it. Not only States can become a party to the Convention, also international organisations can adhere to the Convention, whenever the majority of its member states are a party to it (EEC). The Convention will come into force 12 months after the 60th ratification. The Convention must be viewed as forming one part, this means that it is not possible for the parties to the Convention to make reservations, except whenever the Convention expressly allows it. The complicated character of the Convention together with the possibility of divergent interpretation for various articles, made it necessary to foresee a special conflict regulation. Therefore, an International Law of the Sea Tribunal was created.

11. The Law of the Sea Convention 1982 inaugurates undoubtedly a new era in the evolution of the Law of the Sea. The regulated use of the sea, especially of the high seas, puts an end to the fundamental principle of the traditional law of the sea: the freedom of the high seas. Therefore, it is hardly surprising that the Convention was not generally accepted, specially with regard to the regime of the deep sea bed. Nevertheless, the Convention is an important link in the North-South relations, because it tries by a normative way of working to overcome the antagonisms between the uses of the oceans. Most of the objections against the Convention can be found with the countries of the industrialised world, particularly concerning the rules on deep seabed mining. Nevertheless, it cannot be denied that strong forces work for the Convention. Besides, it cannot be overlooked that many regulations in the Convention have already become a reality. Especially the extension of the national jurisdiction of the coastal States. For instance, the validity of the 200 mile fishery zone or even a 200 mile EEZ, can no longer be disputed.

Characteristic for the new international law of the sea is the shift to a pluridimensional use of the sea. Although navigation still holds a strong position, its predominant character as existing in the traditional law of the sea, is undoubtedly obsolete. Various ways of economic exploitation of the natural resources of the sea, have now become more and more important. Another characteristic is the express territorial predominance over the sea. This means that the extension of the national jurisdiction of the coastal States, implies that more and more areas of the oceans fall under some sort of national or international jurisdiction.The part of the ocean that escapes any form of territorial dominance, becomes always smaller and smaller.

Finally it is striking that the regional policy frame has become more and more important in the new law of the sea. Gradually regional development and cooperation 
in the legal field have taken an important position on various parts of the law of the sea.

The law of the sea Convention of 1982 is undoubtedly the highlight of the evolution to a new law of the sea. Whether the Convention will or will not receive substantial ratification, does not alter this supposition. The development of the law of the sea has evolved in a way that can not be forced back anymore. On the contrary, one may expect that an important evolution still lies ahead.

\section{THE COOPERATION WITH KENYA}

\section{Kenya and the sea}

12. Kenya, as a coastal state, with a coastline estimated to be 450 kilometers in length, is very conscious that it has abundant advantages, rights and obligations arising from the Convention. As a matter of fact Kenyan diplomats took an active part in the negotiations which culminated in the Law of the Sea Convention of 1982. They contributed to the creation of some of the innovative concepts such as the exclusive economic zone and the international seabed area as well as to the development of the legal regime concerning the protection of the marine environment, navigation, scientific research and transfer of technology. The general contribution of the developing states (Group of 77) resulted into the adjustment of the traditional eurocentric approach of the law of the sea in order to develop into a genuine "international" law of the sea.

\section{Development through cooperation in the field of the law of the sea, ocean management and marine policy}

13. The lack of management capability and advanced research to support rational policies for the implementation of the rights (and obligations) acquired in the 1982 Law of the Sea Convention as well as the limited availability of the necessary documentation facilities seriously endangers the position of the developing world in this respect.

The many opportunities that are offered by the 1982 Convention as well as by other conventions in this domain often remain unknown to the Thirld World. This implies the failure of the basic goal i.e. the truly international legal approach on a global scale of the opportunities and problems that are inherent for man within and through the 


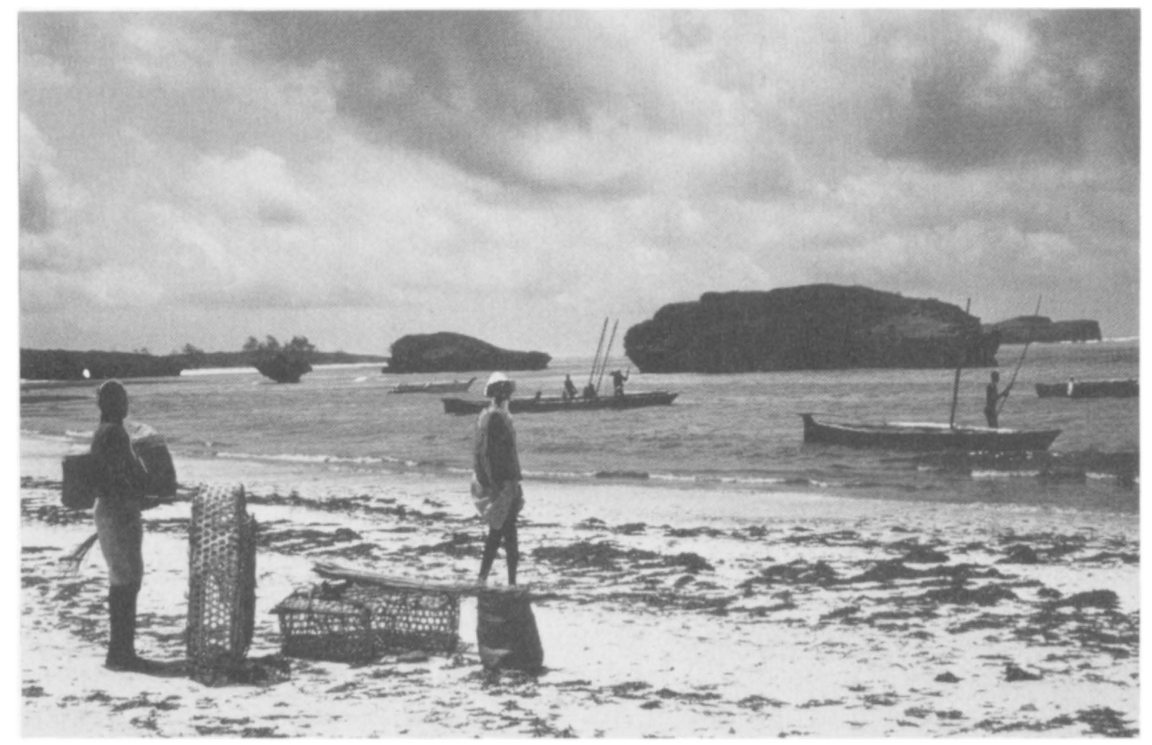

Traditional fishing along the Kenyan coast.

Kenyan diplomats took an active part in the negotiations for the Law of the Sea conference of 1982 . They contribuated by this way also to the development of the legal regime concerning the protection of the marine environment.

(C) D.Beke 
marine environment. The ever progressing normsetting and regulation for all initiatives in the marine field (navigation, fisheries, exploration and exploitation of natural resources of the seabed and subsoil, pollution, scientific research...) implies the necessity for a responsible management policy on the national as well as on the regional and subregional level.

14. There can be no doubt that the implementation of international legal rules in Thirld World states is far from effective. In many cases this is due to the fact that the flow of knowledge in this field within the national legal order is often very far from effectively organised. This unfavourable position restricts efficient management and policy possibilities in many cases. Thus many coastal states of the Third World who enjoy potentially important marine opportunities cannot or rather insufficiently make use of them.

15. The implementation of the 1982 Law of the Sea Convention in East Africa holds tremendous problems and progresses very slowly and difficultly a.o. because of a lack of coordination and effective information between the relevant specialists - who are very few and the several executive authorities in the country. Back in 1985 inspired by the ongoing projects with Kenya in the field of oceanography and marine sciences, an idea took shape to introduce a project that could meet the specific difficulties concerning training, research and cooperation with regard to the legal complications of the new developments in the law of the sea that had recently taken place in UNCLOS III. The fact that Kenya was one of the most developed among the East African states plus the presence of the most important port on the east coast of Africa (Mombasa), as well as the existence of a prima facie adequate basic university potential also contributed to the choice of Kenya as a partner for the envisaged project.

16. In a common effort between Prof. Dr. C. Okidi and Prof. Dr. E. Somers an agreement emerged that was submitted through the channel of the so called "own initiatives" to the VLIR (Flemish Interuniversity Council) in Belgium for appraisal and further financing. This institution decided to give a first priority to the project on the law of the sea, ocean management and marine policy as it was now embodied in a specific cooperation agreement between the University of Ghent and the University of Nairobi. The project was finally approved and financed by the Belgian General Section for Development Cooperation (ABOS) for a period of four years. It is administered at the University of Nairobi by a management committee (with Dr. K. Mavuti as Chairman) and comes under the responsibility of the Office of the Deputy Vice-Chancellor (Academic \& Finance). On the Ghent side the project comes under the management of the Department of Public International Law. 
17. The general objectives of this project are to provide a framework for comparative advanced research and training in the law of the sea, marine policy and ocean management and to bring together the leading academic specialists in marine affairs. Furthermore the project aims at training Kenyan postgraduate students and future scholars in this field and at facilitating the exchange of specialists and students. The purpose will be to develop high level manpower in the areas of the law of the sea as well as in management questions on marine affairs including economics, transportation, sociology, energy, environment and political and security matters, related to ocean uses and resources. In order to provide a thorough scientific background for the realisation of these objectives a corresponding Documentation Centre will be established. This centre will provide for the necessary documents, literature and data bases, specifically aimed at high level research in law of the sea, ocean management and marine policy. The primary goal will be to fulfil the need for information and documentation at the national level.

The necessity for such a Documentation Centre in Nairobi is rendered more glaring by the increasing number of international institutions with responsibilities for subjects which include marine resources and environment. The conclusion of the Convention on the Management and Development of the Marine and Coastal Environment of the Eastern African Region in June 1985 at Nairobi is a case in point. It is important that the coordination centre for the convention is located in Nairobi, the headquarters of UNEP's Oceans and Coastal Areas Programmes Activity Centre. Therefore, the Documentation Centre is supposed to serve vast regional purposes. Thus it can eventually become a comprehensive documentaion system on marine affairs serving East African regional research, training and policy interests. Consequently this Documentation Centre will develop linkages with related institutions established in the region for similar purposes, such as the Recosix project at KMFRI, Mombasa (1).

18. The project is actually in the process of implementation. The basic infrastructure and computer equipment has been installed at the premises of the J. Kenyatta Library of the University of Nairobi (2). Two documentalists have been taken in training. They will assume day to day responsibility concerning the work of the Documentation Centre. A total of 6 Kenyan postgraduates will have the opportunity to come to Belgium for further training and research in their respective fields. So far candidates have been identified within the domain of port management, fisheries and environmental protection. Addional training for one of the documentalists (documentation management on computer) is also provided for in Belgium. In Kenya Belgian visiting experts will contribute to the training of local people at the University of Nairobi.

19. It is expected that the project will result in the expansion and upgrading of the research and training capabilities of Kenyans in the Law of the Sea, Marine Policy 
and Ocean Management. Furthermore it should provide current scientific backing for the development of national policies in Ocean Affairs. Beyond this development it is expected that the project would facilitate the establishment of linkages that would provide for a comprehensive regional East African policy. Finally the project should promote high level academic activities in related subject areas and enrich teaching and research in other departments in the University of Nairobi. It is the solid belief of the project promotors that in these fields development through cooperation is thus becoming a reality.

\section{NOTES}

1. Recosix is a documentation network for academic researchers in the western Indian Ocean region, working under the auspices of the International Oceanographic Commission.

2. The following PC configuration was installed:

- 1 Olivetti M380/XP3 (2 FD MIXED, 2 MB RAM, 135 MB HDU, 80386 processor, 20 Mhz, ESDI HDU controller, interleave 1:1), with monochrome display and extended querti keyboard;

- 3 Olivetti M200 (1FD, 720K, 2MB RAM, 20MB HDU);

- 1 printer NEC $P 6+$

Additional equipment:

- 1 tapestreamer Wangtek 150 MB

- Novell 8 Users ELS

- Arcnet cards P120 (4 stuks)

- $1 H U B$ 
- UPS plus LAN software

- 1 CD Rom Hitachi

- Fax Pitney-Bowes.

- Modem 